Права людини в Україні та у зарубіжних країнах:

проблеми теорії та нормативно-правової регламентації

DOI https://doi.org/10.36059/978-966-397-210-7/208-228

Козакевич О. М.,

аспірантка кафедри загальнотеоретичної юриспруденції Національного університету «Одеська юридична академія»,

м. Odeca

\title{
ОСОБЛИВОСТІ РЕАЛІЗАЦІЇ ПРАВА НА ДОСТУП ДО ПРАВОСУДДЯ У ТРАНЗИТИВНИХ УМОВАХ
}

Анотація. Це дослідження присвячене аналізу сучасних тенденцій реалізації права на доступ до правосуддя. Процес реалізації права на доступ до правосуддя в теперішній ча, характеризується певними особливостями. Для Украӥни, наприклад, це пов'язано із транзитивним періодом, в якому перебуває суспільство. Під впливом транзитивних процесів система правосуддя зазнає значних трансформацій. Одним із напрямків таких змін $\epsilon$ формування сучасної концепції доступності правосуддя. Основна ідея даної концепції полягає у формуванні такої системи правосуддя, яка, в першу чергу, буде сприяти зменшенню організаційних бар'єрів для належної реалізації громадянами права доступу до правосуддя. Важливим аспектом щодо досягнення даної мети слід вважати впровадження новітніх інформаційних технологій у судочинстві.

\section{Вступ}

Право є відображенням глибинних тенденцій і процесів, що відбуваються як у кожному окремому суспільстві, так у світі в цілому. Під впливом викликів сучасності виникає потреба орієнтуватись не тільки на традиційний досвід у правовій сфері, але і враховувати динамічні зміни в суспільстві, пов'язані із транзитивними процесами. Транзитивний період $\epsilon$ перехідним етапом розвитку будьякого суспільства. Транзитивність характеризується зміною ціннісно-нормативних орієнтирів, під впливом яких змінюються основні соціальні і правові інститути. 
Забезпечення прав та свобод людини є основоположною ідеєю існування сучасної держави, певним стандартом демократії, основою формування громадянського суспільства. Саме тому одним із проявів транзитивності у правовій сфері $\epsilon$ зміни, що відбуваються $\mathrm{d}$ системі правосуддя i, в першу чергу, в аспекті його доступності.

Право на доступ до правосуддя в системі прав людини має першорядне значення, оскільки являє собою систему правомочностей, які спрямовані на реалізацію та захист всіх інших прав, свобод та інтересів людини. У сучасних умовах реалізація права на доступ до правосуддя пов'язана із транзитивними процессами, що відбуваються в державі. Ці зміни детермінують правовий розвиток, зумовлюють специфіку сучасного права. Значних трансформацій зазнають механізми правореалізації, правозастосування. Зміни ціннісних орієнтирів впливають на рівень правової культури та правосвідомості в суспільстві. Усе це впливає на умови здійснення судочинства, спрямовує зусилля держави на забезпечення та дотримання демократичних принципів у судовому процесі, актуалізує важливість забезпечення права кожної людини на доступ до правосуддя.

Слід зазначити, що в сучасній Україні виникають певні проблеми 3 належною реалізацією права на доступ до правосуддя. Саме тому сьогодні $\epsilon$ важливим аналіз шляхів подолання зазначених проблем, а також вивчення позитивного досвіду інших країн щодо організації системи правосуддя, та безумовної реалізації права на доступ до правосуддя.

\section{1. Забезпечення права на доступ до правосуддя як складник сучасних трансформаційних процесів}

Світ $\epsilon$ сукупністю надзвичайно різноманітних суспільств, правових систем, що взаємодіють, проте співіснування яких постійно видозмінюється під впливом тенденцій і викликів часу. Людство пройшло 
Права людини в Україні та у зарубіжних країнах:

проблеми теорії та нормативно-правової регламентації

доіндустріальну та індустріальну стадії розвитку. 3 останньої чверті XX ст. настав перехідний період до постіндустріального, або інформаційного суспільства.

У кожну історичну епоху формувався свій тип праворозуміння, який зумовлював особливості формування та розвитку національних правових систем. Індустріальна епоха характеризувалась промислово розвиненою системою, визначала індивідуалістичну спрямованість правових інститутів, важливість прав і свобод особистості, визначне місце закону. Західне індустріальне суспільство, орієнтирами якого були гедонізм та прагматизм, досягло значних успіхів, що дозволило не лише технологічно, а й світоглядно претендувати на домінуючі позиції у світі. Людина індустріального суспільства була спрямована на матеріальні цінності, що призвело до духовної кризи того часу. Перехід до постіндустріального суспільства, з його новітніми цінностями i спрямованістю на всебічний розвиток людини, сприяє подоланню цього кризового стану.

Взагалі термін «постіндустріальне суспільство» вперше було вжито після Другої світової війни американським юристом та соціологом Девідом Рісменом у 1958 році $[1$, c. 364]. У соціальних науках для позначення даного типу суспільства використовуються також поняття «інформаційне суспільство» (Й. Масуда), «технотронне суспільство» (3. Бжезинський), «наукове суспільство» (М. Понятовський), «суперіндустріальна цивілізація», «третя хвиля» (Е. Тоффлер). Значний теоретичний внесок у розробку концепції нового суспільства було зроблено Д. Беллом у його праці «Прийдешнє постіндустріальне суспільство», в якій визначено, що постіндустріальне суспільство робить наголос на центральній ролі теоретичного знання як осі, навколо якої вибудовується нова технологія та розвиток всіх соціальних сфер [2, с. 50].

Базисом постіндустріального суспільства $€$ знання, що не віддільні від людини. Це й зумовило підсилену увагу до людини, ïi інтелектуальних здібностей, прав та свобод. Саме в сучасний період актуалізувались питання визнання 
та захисту прав людини. Це призводить до суттєвих змін у правовій сфері, а саме до формування і розвитку інституту захисту прав людини та його нормативно-правової регламентації. Крім того, на межі XX - XXI ст. з'явилась концепція формування «Knowledge society», «К-суспільства» або «суспільства, заснованого на знаннях». Це суспільство, яке визначається як вищий ступінь розвитку постіндустріального суспільства та характеризується, крім технологічного, соціальним, ідеологічним та правовим вимірами [3, с. 245-355]. Його невід'ємними компонентами стали міждисциплінарні знання, що генеруються соціальними та правовими інститутами, i суспільство, зорієнтоване на підвищення якості життя та належної реалізації громадянами усіх їхніх прав.

Постіндустріальний світ перебуває лише на початковому етапі становлення. Саме тому у великій кількості держав відбуваються трансформаційні зміни по переходу від авторитарних та тоталітарних форм правління до демократії та від індустріального до інформаційного суспільства. Зазначений період визначається як транзитивний.

Термін «транзиція» $\epsilon$ найбільш узагальнюючим по відношенню до таких категорій, як «перехід» i «трансформація», та вказує на незавершеність руху, процес, спрямований у майбутнє [4, с. 14]. Транзитивний процес являє собою динамічний перехід суспільства та основних соціальних інституцій на новітній ступінь розвитку. Він $\epsilon$ історичною закономірністю, але слід зазначити, що перехід на прогресивно новий рівень розвитку часто ускладнюється внутрішніми протиріччями. Статичні компоненти, що властиві попередньому періоду розвитку суспільства, заважають позитивним перетворенням.

Транзитивне суспільство визначають як певний етап розвитку суспільства, що характеризується суттєвою трансформацію усіх або більшості соціальних інститутів, цінностей та норм, які зумовлюють виникнення нових 
соціальних структур та змін в організації управління суспільством, якому властиві такі ознаки: невідповідність соціальних інститутів реальним суспільним потребам; зміни у соціальній структурі; руйнування бар'єрів та виникнення нових; зміни ідентичності індивіда; трансформація соціальних інститутів, що включає їх деформацію, вдосконалення; зміни в організації управління суспільством; зміна цінностей $\epsilon$ особливо важливим компонентом транзитивного періоду в житті суспільства; зміна нормативного регулювання [4, с. 15].

Свій прояв транзитивність знаходить у правовій сфері. Транзитивність $\epsilon$ закономірною властивістю права, що проявляється в рефлексії права на соціальну транзицію та в закріпленні результатів соціальної транзиції правовими засобами [4, с. 7]. Під впливом цих тенденцій здійснюється розвиток нормативної сфери права, формуються нові за змістом правові норми, інститути, галузі, змінюється система правореалізації та правозастосування.

Особливості формування права в транзитивний період зумовлюються орієнтиром на ідеали сучасного правового розвитку. Із цією метою нормативно закріплюються нові правові цінності, трансформуються, а то й відкидаються усталені правові позиції, впроваджуються у свідомість нові правові установки. Особливу роль у транзитивний період відіграє правоутворення, яке залежить від взаємодії цінностей різного рівня, від загальнолюдських до цінностей соціальної та/або етнічної групи [4, c. 21]. До загальнолюдських цінностей слід віднести, перш за все, права людини, які особливо гостро сприймаються у транзитивних суспільствах, що долають наслідки тоталітаризму або авторитаризму.

Транзитивні зміни знайшли своє відображення в системі правосуддя, а саме в доступності правосуддя як однієї 3 його центральних характеристик. Доступність правосуддя втілює механізм реалізації одного з основних прав людини - права на захист своїх законних прав та 
інтересів за допомогою правосуддя як найбільш демократичного та ефективного інструменту захисту.

Аналіз положень міжнародного та національного законодавства свідчить про те, що гарантія доступності правосуддя встановлюється як на міжнародному рівні в нормативно-правових актах, дію яких визнано Україною, так i на державному рівні шляхом закріплення в положеннях основного закону держави - Конституції України, та в інших нормативно-правових актах українського законодавства. Так, ст. 6 Конвенції про захист прав людини та основоположних свобод 1950 року (далі Конвенція) передбачено, що кожен має право на справедливий і публічний розгляд його справи впродовж розумного строку незалежним і безстороннім судом, установленим законом, який вирішить спір щодо прав та обов'язків цивільного характеру або встановить обгрунтованість будь-якого висунутого проти нього кримінального обвинувачення [5]. Відповідно до ст. 55 Конституції України кожному гарантується право на оскарження в суді рішень, дій чи бездіяльності органів державної влади, органів місцевого самоврядування, посадових і службових осіб [6]. Вказані правомочності в юриспруденції розглядаються як складові частини права на доступ до правосуддя.

Слід зазначити, що ні Конвенція, ні норми національного законодавства України не дають визначення «права на доступ до правосуддя». Водночас вказане поняття досить широко застосовується у судовій практиці та правовій доктрині. Національні суди керуються, зокрема, дефініціями Європейського суду з прав людини, який визначає право на доступ до правосуддя 3 огляду на реальну можливість реалізації низки процесуальних прав:

- на звернення до суду за захистом своїх прав, свобод та законних інтересів (рішення у справі «Голдер проти Сполученого Королівства» [7]); 
- на ефективну участь у провадженні (рішення у справі «Лучанінова проти України» [8]);

- на оскарження судових рішень, якщо закон передбачає створення апеляційних та/або касаційних судів (рішення у справі «Гоффман проти Німеччини» [9]);

- на виконання рішень (рішення у справі «Аннонні ді Ґюссоль та інші проти Франції» [10]) тощо.

Практика Європейського Суду із прав людини (ЄСПЛ) з питань доступності правосуддя бере свій початок зі справи Голдер проти Сполученого Королівства (справа Голдера) від 21 лютого 1975 р. Дане рішення закріпило фундаментальні основи права на доступ до правосуддя. Концептуальною ідеєю рішення у справі Голдера $\epsilon$ «право доступу», в якому ЄСПЛ фактично вперше вивів з тексту Конвенції зазначене право. Формування категорії «доступності правосуддя» стало можливим внаслідок того, що Суд розглянув судовий процес не шляхом текстуального тлумачення статті 6 Конвенції, а перш за все крізь призму ефективності правового захисту. Заперечення існування доступу до правосуддя могло б привести як до неефективності статті 6 Конвенції, так і загалом до обмеження доступу до системи захисту прав людини. На цей факт вказує і сам Європейський Суд з прав людини, відзначаючи у справі Голдера, що право на доступ до суду охоплює не тільки вже розпочатий процес, але і саму можливість ініціювати судову процедуру [7]. Як наслідок, в юриспруденції справа Голдера цілком обгрунтовано ототожнюється 3 конкретизацією права на доступ до правосуддя та стала основою для осмислення теоретичних питань доступності правосуддя та зародження ряду правових доктрин.

У сучасних наукових дослідженнях право на доступ до правосуддя розглядають у вузькому та широкому сенсах. У вузькому сенсі - як можливість скористатися правовими засобами класичного правосуддя або лише як формальну можливість особи з'явитися в суді. Так, Ю. Матат під 
доступом до правосуддя розуміє здатність особи безперешкодно отримати судовий захист як доступ до незалежного й безстороннього вирішення спорів за встановленою процедурою на засадах верховенства права $[11$, c. 20]. На думку I. Верби, право на доступ до правосуддя слід визначати як право людини, що передбачає можливість безперешкодного звернення до суду з метою захисту своїх прав, свобод [12, с. 20].

За широкого підходу право на доступ до правосуддя припускає необхідність подолання різних бар'єрів в системі правосуддя та пов'язане із соціально-економічним контекстом. В умовах транзитивних змін пріоритетним $\epsilon$ широке розуміння досліджуваного поняття. Право на доступ до правосуддя в цьому випадку розглядається через сутність та призначення категорії «правосуддя», а не лише у площині «доступності», оскільки передбачає реальний характер судового захисту та включає в собі змістовні характеристики правосуддя, а не лише окремі правомочності та організаційні аспекти. Саме за такого підходу право на доступ до правосуддя буде забезпеченим та реалізованим в повній мірі.

Слід відзначити, що під впливом транзитивних процесів у правовій сфері відбулося формування повноцінної теоретичної концепції правосуддя в 70-ті роки XX століття, яке пов'язане із втіленням «Флорентійського проекту». Основна мета Флорентійського проекту полягала у формуванні сучасної теорії доступності правосуддя. Iї базисом стала робота професора Мауро Каппеллетті «Доступність правосуддя». Основною ідеєю зазначеної роботи $\epsilon$ зміна теоретико-правового підходу до правосуддя. М. Каппеллетті критикував домінуючий в той час ліберально-буржуазний підхід до права і правосуддя, який передбачав формалізоване розуміння права на доступ до правосуддя. Відповідно до цього підходу держава не заперечує факт існування природних прав, проте не вживає дій, спрямованих на сприяння в їх реалізації. 
Права людини в Україні та у зарубіжних країнах:

проблеми теорії та нормативно-правової регламентації

Досягненням М. Каппеллетті був розгляд природи бар'єрів у доступі до правосуддя. 3 одного боку, він визнавав, що певні бар'єри під час звернення до суду повинні бути: доступ до суду не може бути хаотичним, тому процедура звернення до суду повинна бути так або інакше врегульована. 3 іншого ж боку, такі бар'єри не повинні порушувати права людини, оскільки $є$ ймовірність того, що право на доступ до правосуддя стане лише формальним, а його реалізація неможливою. Серед подібних бар'єрів, М. Каппеллетті виділяв організаційні, фінансові, економічні та адміністративні перешкоди.

Одним із підсумків Флорентійського проекту став «рух за доступ до правосуддя» - як комплекс заходів, спрямованих на забезпечення реального характеру доступу до правосуддя. Такі заходи М. Каппеллетті класифікував на три групи, які назвав «хвилями». Кожна «хвиля», по суті, була похідна від бар'єрів, що перешкоджали доступу до правосуддя: 1) усунення соціальних перешкод (реформування ринку юридичної допомоги, оптимізація системи розподілу судового збору); 2) реформування інститутів захисту прав різноманітних груп осіб; 3) впровадження систем альтернативного вирішення спорів. Саме завдяки М. Каппеллетті багаточисельні ідеї щодо доступності правосуддя були систематизовані і зведені в єдину концепцію. Відмінною рисою даної концепції $€$ не тільки ії теоретична значущість та міждисциплінарний характер (вона поєднує напрацювання філософії, соціології, юриспруденції), але і її практична спрямованість [13, с. 196].

Сучасний структурований підхід щодо права на доступ до правосуддя запропонувала Крістін Паркер, яка виділяє чотири покоління підходів до розуміння та реформування вказаного права:

- доступ до правосуддя як рівний доступ до правової допомоги та судів через надання відповідних державних субсидій та іншої правової підтримки; 
- доступ до правосуддя як усунення дисбалансу в межах системи правосуддя, що виражений у зміні законів та судових процедур, судової практики 3 метою забезпечення чіткого порядку реалізації вказаного права;

- доступ до правосуддя, що охоплює широке застосування змагальних та незмагальних альтернатив класичного правосуддя;

- поліпшення доступу до правосуддя шляхом створення відповідного конкурентного середовища, що дало б змогу забезпечити доступ до правосуддя найбільш продуктивно, наприклад, шляхом реформи юридичної професії для зменшення вартості правової допомоги $[14$, c. 30$]$.

Через реалізацію прав розкриває поняття права на доступ до правосуддя i Конституційний Суд України в своєму рішенні від 12.04.2012 р. № 9-рп/2012 [15]. У цьому рішенні зазначається, що право на доступ до правосуддя охоплює можливість особи ініціювати судовий розгляд та брати безпосередню участь у судовому процесі. При цьому наголошується на тому, що ніхто не може бути обмежений у такому праві або його позбавлений.

\section{2. Шляхи реалізації права на доступ до правосуддя в сучасних умовах}

Після 1991 року в Україні було розпочато курс на побудову суспільства, заснованого на демократичних засадах. Проте українське суспільство сьогодні ще знаходиться у стані глибокої, системної кризи, пов'язаної з особливостями транзитивного періоду розвитку держави. Так, наявність лише декларативних гасел, а не реальних змін, зумовлює втрату довіри громадян до правових інститутів, системи правосуддя, правоохоронних органів, що призводить до розповсюдження нігілістичного ставлення до права.

Одна із центральних ідей зміни концепції правосуддя в транзитивний період полягає в тому, що суспільство 
Права людини в Україні та у зарубіжних країнах:

проблеми теорії та нормативно-правової регламентації

перебуває між станом, коли мали місце численні порушення прав людини, і станом стабільності й миру. При цьому постконфліктні, поставторитарні обставини $\epsilon$ достатньо значними чинниками інституційної реформи. Адже державна влада перебуває у глибокій кризі, а інституційна складова частина фрагментована $[16$, с. 8]. В юриспруденції виділяють певні внутрішні фактори, що визначають ефективність змін у доступі до правосуддя в поставторитарних суспільствах:

1) демократія - демократичні режими більш спрямовані на встановлення рівності, справедливості, оскільки засновані на засадах відкритості урядування й прагненні задовольнити вимоги суспільства; здійснення правосуддя над тим, хто винен у масштабних порушеннях прав людини;

2) визнання та захист прав людини - реагування на масштабні порушення прав людини в минулому, повага держави до концепції прав людини в цілому створює належні передумови для ефективних механізмів правосуддя;

3) співвідношення владних сил попереднього режиму, з одного боку, і громадянського суспільства, з іншого, - від такого співвідношення залежить ефективність механізмів правосуддя в період транзитивності;

4) рівень громадської підтримки попереднього режиму $[16$, c. $10-11]$.

Права та свободи людини $€$ основним цінніснонормативним орієнтиром сучасних демократичних трансформацій суспільства. Право на доступ до правосуддя має першорядне значення серед усіх індивідуальних та колективних прав, оскільки являє собою механізм їх захисту. У транзитивних умовах посилюється роль держави в забезпеченні комплексу заходів, спрямованих на реалізацію громадянами права на доступ до правосуддя. Перш за все, це полягає в неприпустимості встановлення державою будь-яких організаційних, економічних, 
перешкод на шляху до правосуддя. Ці бар'єри не повинні порушувати права людини, оскільки є ймовірність того, що право на доступ до правосуддя стане лише формальним, а його реалізація неможливою. Тобто роль держави в забезпеченні права на доступ до правосуддя має полягати як в утриманні від учинення фактичних та адміністративних перешкод у його реалізації, так і в активних діях, орієнтованих на створення та спрощення процедури забезпечення цього права. Процес взаємодії держави та особи є одним із індикаторів стану суспільних змін на шляху до втілення загальнолюдських цінностей.

Аналіз резолюцій і рекомендацій Комітету Міністрів Ради Європи дозволяє вирізнити такі критерії доступності правосуддя:

- обов'язок держави забезпечити надання адвокатом високопрофесійної правової допомоги особам, які через скрутний матеріальний стан не в змозі їі самостійно оплатити;

- інформування громадськості про юрисдикцію та місцезнаходження судів, а також про порядок звернення до суду для захисту своїх прав, свобод та інтересів у судовому порядку;

- застосування спрощених судових процедур;

-скорочення або анулювання судових витрат, якщо вони стають перешкодою для доступу до правосуддя;

- вжиття заходів, спрямованих на усунення зловживань правом особи на звернення до суду;

- забезпечення судових органів найсучаснішими технічними засобами;

- використання альтернативних засобів розв'язання правових конфліктів із поступовим зменшенням завдань, не пов'язаних із вирішенням спору про право, які покладаються на суд;

- створення сучасних автоматизованих систем зберігання судових рішень із забезпеченням належного доступу до них; 
Права людини в Україні та у зарубіжних країнах:

проблеми теорії та нормативно-правової регламентації

- вжиття заходів, спрямованих на підвищення ефективності управління інфраструктурою, фінансами, людськими ресурсами й засобами зв'язку в системі правосуддя;

- гарантії незалежності та неупередженості суддів під час здійснення правосуддя [16, с. 459].

Ураховуючи реалії функціонування, та розвитку правової системи України, слід зазначити, що певна частина зазначених критеріїв щодо доступності правосуддя не забезпечується належним чином. Навпаки, виникають певні обмеження в механізмі реалізації громадянами права на доступ до правосуддя.

Сучасне українське правосуддя характеризується інституційними змінами. Офіційно судова реформа в Україні почалася в 2014 році, орієнтиром якої було досягнення стандартів Європейського Союзу. Процес реформування супроводжувався прийняттям Верховною Радою України низки законодавчих змін, основні положення яких відображені в таких нормативно-правових актах: Закон України «Про забезпечення права на справедливий суд» від 12 лютого 2015 року, Закон України «Про судоустрій і статус суддів», Закон України «Про внесення змін до Конституції України(щодо правосуддя)» від 02 червня 2016 року, Закон України «Про внесення змін до Господарського процесуального кодексу України, Цивільного процесуального кодексу України, Кодексу адміністративного судочинства України та інших законодавчих актів» від 03 жовтня 2017 року.

Реформа правосуддя в Україні повинна була мати спрямованість на забезпечення реального втілення в життя прав і свобод людини. Проте її реалізація не сприяла розширенню механізмів доступу до правосуддя. Навпаки, українська система правосуддя зберегла каральну спрямованість та бар'єри в доступі громадян до правосуддя. 
Одним із напрямів судової реформи було втілення закріпленого в Конституції, належного функціонування судової системи як однієї із трьох незалежних гілок влади. Для цього передбачалося повністю вилучити вплив політичних чинників на призначення суддів, позбавивши орган законодавчої влади даної функції. У результаті прийняття законів «Про внесення змін до Конституції України (щодо правосуддя)» i «Про судоустрій i статус суддів» право призначати суддів перейшло до президента. Наявність у процедурі кваліфікаційного оцінювання добору суддів такого суб'єктивного елемента, як співбесіда із членами Вищої кваліфікаційної комісії суддів, на яку вирішальний вплив має президент, продовжує тенденцію посилення контролю інших гілок влади над судовою системою $[17$, c. 205]. Таким чином, через політичний вплив на судову систему порушується гарантія незалежності суддів, що є одним із елементів доступності правосуддя.

Ще одним результатом реформування правосуддя $є$ той факт, що витрати на функціонування судової системи збільшуються, а не зменшуються, всупереч задекларованим цілям реформи. Значна частка судових витрат йде на процеси реорганізації судів та проведення кваліфікаційних перевірок суддів, ефективність яких вкрай сумнівна, зважаючи на кадровий дефіцит суддів. Ці факти призводять до того, що деякі суди існують лише фактично, не здійснюючи при цьому правосуддя.

Проте найбільше перешкод у реалізації громадянами права доступу до правосуддя пов'язано із прийняттям Закону України «Про внесення змін до Господарського процесуального кодексу України, Цивільного процесуального кодексу України, Кодексу адміністративного судочинства України та інших законодавчих актів» від 03 жовтня 2017 року, який встановив ряд бар'єрів доступу до справедливого і незалежного правосуддя. Одним із таких бар'єрів стало зростання розміру судового збору, який збільшився в десятки разів із прийняттям нового 
законодавства. Ставки судового збору настільки великі, що позбавляють більшість громадян можливості звертатись до суду. Крім того, в разі невнесення стороною спору, коштів судового збору суд має право залишити позов без розгляду. Усе це обмежує право доступу громадян до правосуддя, ставить його в залежність від матеріального становища особи.

Суттєвих обмежень зазнають громадяни під час реалізації доступності правосуддя на касаційному етапі розгляду справ. Відповідно до ст. 328 Кодексу адміністративного судочинства України судові рішення у справах незначної складності не підлягають касаційному оскарженню, крім випадків, визначених у тексті Кодексу такими «оціночними» категоріями, як: фундаментальне значення; значний суспільний інтерес; виняткове значення для учасника справи [18]. Ці поняття не розтлумачені в тексті закону, що позбавляє громадянина гарантованого права на доступ до правосуддя. Крім того, Касаційному адміністративному суду надаються повноваження визнання касаційної скарги необгрунтованою ще до стадії іiї розгляду. Таким чином, можуть виникати ситуації, коли аналогічні справи будуть переглядатися в касаційному порядку залежно від певного складу суду, а не наявності законних підстав для такого перегляду. Це в підсумку впливатиме на гарантію неупередженості суддів.

Значною перешкодою в доступності правосуддя стало закріплення нормативного положення про те, що суд може не проголошувати публічно судові рішення, прийняті за результатами закритих судових засідань, що порушує статтю 6 Конвенції із прав людини, де вказано, що судові рішення в будь-якому випадку проголошуються публічно $[17$, c. 200].

Слід зазначити, що в сучасній Україні правосуддя характеризується наявністю негативних тенденцій не лише в аспекті реалізації кожним громадянином права доступу до правосуддя, а й загалом відносно всієї системи правосуддя. Визначається відставання правосуддя від 
прогресивних правових вимог суспільства. У нормативноправових актах, що регулюють суспільні відносини у сфері забезпечення здійснення правосуддя, велика кількість формулювань, які порушують конституційну вимогу для органів влади діяти лише на підставі і в рамках закону: «суд може», «суд має право», «визнається судом», «за ініціативою суду», «суд сприяє примиренню сторін» $[17$, с. 204]. У цьому випадку закон виходить за межі права і стає знаряддям свавілля, який зумовлює регресивний розвиток правової сфери.

Одним із важливих кроків на шляху до ефективної реалізації громадянами права на доступ до правосуддя в сучасний, транзитивний період слід вважати впровадження новітніх інформаційних технологій у систему правосуддя.

Новації сучасної доби багато в чому пов'язані із втіленням новітніх інформаційних технологій у процеси обробки правової інформації та прийняття юридично значущих рішень. Наприклад, з'являються такі процеси та явища, як електронне урядування, електронна демократія, електронний документообіг, електронний суд та ін. Під впливом динамічних процесів інформатизації активно застосовуються інформаційні технології в судовій системі та судочинстві. Ці фактори зумовлюють формування електронного правосуддя, що суттєво змінює правосуддя в контексті його доступності.

Електронне правосуддя являє собою певну систему, що складається 3 елементів, які забезпечують доступ до інформації про діяльність судів і систем автоматизації судочинства. Основна мета електронного правосуддя полягає в забезпеченні безперешкодної реалізації громадянами права доступу до правосуддя, спрощенні провадження низки процесуальних дій для громадян. У цьому контексті важливого значення набувають положення кримінального процесуального законодавства. Зокрема, Кримінальний процесуальний кодекс України передбачає застосування відеоконференції під час 
досудового розслідування у процесі проведення допиту, впізнання. Стаття 232 КПК України детально регламентує умови застосування цієї технології та ії процесуальне оформлення. Хід i результати процесуальних дій, проведених у режимі відеоконференції, фіксуються за допомогою технічних засобів відеозапису [19].

У ряді випадків такі технології роблять доступ до суду єдиним можливим способом. Як наслідок, право на доступ до правосуддя розглядається не лише як фізична можливість особи бути присутньою в судовому засіданні, а в аспекті новітніх технологій, дій і процедур допоміжного характеру щодо забезпечення i полегшення шляхів реалізації права на доступ до правосуддя [16, с. 371]. Слід зазначити, що право на доступ до правосуддя в цьому аспекті розглядається не лише як правова категорія, a i крізь призму соціального контексту, в якості соціальної категорії, що оперує насамперед загальнолюдськими цінностями і правом кожної особи на захист своїх прав, свобод та законних інтересів. Як наслідок, реалізація права на доступ до правосуддя розглядається як шлях до вирішення соціальної несправедливості.

Україна теж знаходиться на шляху до формування системи електронного правосуддя. Значне місце в роботі судів має реалізація проекту «Електронний суд», що запроваджує обмін електронними документами між судом та учасниками судового процесу [20]. Адже ведення та збереження документації суду в електронному вигляді забезпечить безперешкодне право на доступ громадян до правосуддя навіть у разі припинення робити суду за об'єктивних (надзвичайних) обставин та подальшого територіального переміщення судової установи в іншу місцевість.

Наразі перші кроки в напрямку реалізації проекту «Електронний суд» в Україні вже зроблені. Електронна підсистема суду працює у відкритому доступі ESITS та забезпечує безпечний обмін файлами, що стосуються того чи іншого судового процесу через електронний кабінет. 
Безперечно, впровадження таких новацій сприятиме зменшенню організаційних, адміністративних та часових витрат, що виникають під час подання процесуальних документів до суду в паперовій формі. До того ж електронне судочинство забезпечить учасникам справи право брати участь у судовому засіданні незалежно від їхного місця перебування (місця проживання). Такі зміни сприятимуть усуненню організаційних бар'єрів громадян до реалізації права на доступу до правосуддя, що сприятливо відобразиться на всій системі правосуддя та зумовить позитивні тенденції на правосвідомості суспільства.

Проте в деяких випадках новітні технології можуть значно обмежити реалізацію доступу до правосуддя. Це може стосуватись, наприклад, осіб, які не володіють навичками роботи із сучасними інформаційними технологіями або не мають відповідного технічного обладнання. У такому випадку право на доступ до правосуддя буде значно звужено, а за відсутності фінансових можливостей отримати професійну допомогу взагалі стає неможливим. 3 урахуванням даного фактора встановлення електронної судової комунікації як єдиної форми спілкування учасників судового процесу, коли право використання електронних технологій переходить в обов'язок, буде створювати надмірні перешкоди на шляху звернення до суду і обмежувати доступність правосуддя як можливість належної реалізації громадянами права на захист своїх прав, свобод та законних інтересів.

\section{Висновки}

Сьогодні Україна знаходиться в умовах перетворень, пов'язаних із транзитивним періодом її розвитку. На шляху побудови демократичного суспільства відбуваються значні зміни, в тому числі і у правовій сфері. Важливою ознакою та певним маркером демократії в сучасному світі $\epsilon$ належне забезпечення та безперешкодна реалізація доступу до правосуддя. 
Якщо в XIX столітті право на доступ до правосуддя визначалось як формальне право особи на судовий розгляд спору, включаючи лише фізичний доступ особи в будівлю суду та участь у процесі, то останнім часом відбувається модернізація права на доступ до правосуддя. Під впливом сучасних процесів сформувалась повноцінна теоретична концепція, в якій доступність правосуддя визначається як повноцінний комплекс заходів, спрямованих на забезпечення реального доступу громадян до правосуддя. Ця концепція розкриває залежність правосуддя від цілої сукупності умов і необхідності подолання низки бар'єрів.

Сучасна система правосуддя в Україні потребує значних змін, орієнтиром яких повинна слугувати людина, ïï права та свободи. Для досягнення цієї мети важливим $\epsilon$ зменшення бар'єрів щодо доступу до правосуддя.

Слід зазначити, що новітні технології сприяють прогресивним трансформаціям системи правосуддя, оскільки за допомогою електронних технологій доступ до правосуддя значно спрощується. Умовою ефективності застосування сучасних інформаційних технологій у суді виступає належне забезпечення права на доступ до правосуддя. Електронне правосуддя представляється лише певною технологією, що дозволяє на сучасному етапі розвитку суспільства зробити правосуддя більш доступним та ефективним.

Таким чином, на сучасному етапі розвитку право на доступ до правосуддя слід розглядати в якості комплексної, інтегративної соціально-правової категорії, що динамічно розвивається, та орієнтованої на надання i забезпечення системи гарантій для здійснення і захисту прав, свобод і законних інтересів громадян.

\section{Список використаних джерел:}

1. Riesman D. Leisure and Work in Post-Industrial Society / Larrabee E., Meyersohn R. (Eds.). Mass Leisure. Glencoe (III), 1958. P. 363-385. 
2. Белл Д. Грядущее постиндустриальное общество: опыт социального прогнозирования / пер. с англ. В.Л. Иноземцева. Москва : Academia, 1999. 956 с.

3. Drucker P.F. The Age of Discontinuity: Guidelines to our Changing Society. London : Heinemann, 1969. 420 p.

4. Матвєєва Л.Г. Транзитивність у правовій сфері: загальнотеоретичне дослідження : автореф. дис. на здобуття наук. ступеня канд. юрид.наук : 12.00.01. Одеса, 2016. 36 c.

5. Конвенція про захист прав людини та основоположних свобод від 04.11.1950 року. URL: https://zakon.rada.gov.ua/laws/card/995_004 (дата звернення: 03.03.2020).

6. Конституція України : закон України від 28.06.1996 року.№ 254к/96-BP. URL: https://zakon.rada.gov.ua/laws/ card/254к/96-вр (дата звернення: 03.03.2020).

7. Рішення у справі «Голдер проти Великої Британії» від 21.02.1975. URL: http://zakon.rada.gov.ua/laws/show/ 980_086 (дата звернення: 04.03.2020).

8. Рішення у справі «Лучанінова проти України». URL: https://zakon.rada.gov.ua/laws/show/974_788 (дата звернення: 04.03.2020).

9. Рішення у справі «Гоффманн проти Німеччини». URL: http://www.rrpoi.narod.ru/echr/anouther_3/hoffmann.htm (дата звернення: 04.03.2020).

10. Рішення у справі «Аннонні ді Гюссоль та інші проти Франціï». URL: https://www.echr.coe.int/Documents/ Guide_Art_6_UKR.pd (дата звернення: 04.03.2020).

11. Матат Ю. Право на доступ до суду: європейська традиція та проблеми забезпечення в Україні. Національний юридичний журнал: теорія і практика. 2017. № 6. С. 19-23.

12. Верба I.О. Право на доступ до правосуддя як об'єкт наукового аналізу: юридичний аспект. Порівняльноаналітичне право. 2015. № 6. С. 19-22. 
13. Garth Bryant G. and Cappelletti Mauro Access to Justice: The Newest Wave in the Worldwide Movement to Make Rights Effective. Maurer School of Law: Indiana University, 1978. $1142 \mathrm{p}$.

14. Parker C. Just Lawyers: regulation and access to justice. Oxford : Oxford University Press, 1999.278 p.

15. Рішення Конституційного Суду України від 12.04.2012 р. № 9-рп/2012. URL: https://zakon.rada.gov.ua/ laws/show/v009p710-12 (дата звернення: 03.03.2020).

16. Базове дослідження із застосування правосуддя перехідного періоду в Україні : монографія / за заг. ред. А.П. Бущенка, М.М. Гнатовського. Київ : «РУМЕС», 2017. 592 с.

17. Цена реформ / за ред. В.М. Якушика. Дніпро : Середяк Т.К., 2019. 209 с.

18. Кодекс адміністративного судочинства України : Закон України від 06.07.2005 року. № 2747-IV URL: https://zakon.rada.gov.ua/laws/show/2747-15 (дата звернення: 11.04.2020).

19. Кримінальний процесуальний кодекс України : Закон України від 13.04.2012 року. № 4651-VI. URL: https://zakon.rada.gov.ua/laws/card/4651-17 (дата звернення: 03.03.2020).

20. Про реалізацію проекту щодо обміну електронними документами між судом та учасниками судового процесу : наказ Вищого адміністративного суду України від 20.01.2015 № 3. URL: https://zakon.rada.gov.ua/laws/ show/v0003760-15 (дата звернення: 03.03.2020). 